\title{
Dynamics of solar bleaching in the intertidal reef coral Goniastrea aspera at Ko Phuket, Thailand
}

\author{
Martin D'A. A. Le Tissier*, Barbara E. Brown \\ Department of Marine Sciences and Coastal Management, University of Newcastle upon Tyne, Newcastle upon Tyne NE1 7RU, \\ United Kingdom
}

\begin{abstract}
The bleaching response in intertidal Goniastrea aspera (Verrill) was investigated immediately at the onset of a natural bleaching event caused primarily by elevated solar irradiance. Bleaching was found to involve a significant decrease in zooxanthellae density and a significant reduction in chlorophyll $c$ content of zooxanthellae. In contrast chlorophyll a content of zooxanthellae appeared to increase in bleached compared to normally pigmented tissues, an effect which may have been the result of interference of chlorophyll breakdown products with the pigment analysis. Bleaching damage was restricted at the cellular level to those host endodermal cells harbouring zooxanthellae, both of which exhibited cellular degradation. In bleached tissues, in situ degradation of zooxanthellae, prior to their loss from host tissues, appeared to be the principal factor associated with reduction in algal density. The results highlight that the mechanism of bleaching is a complex response involving changes in the symbiotic association between specific host and zooxanthella cells, zooxanthella densities and pigment content.
\end{abstract}

KEY WORDS: Coral Z Zooxanthellae Symbiosis Bleaching

\section{INTRODUCTION}

Bleaching (loss of pigmentation) in corals is a characteristic response to environmental perturbation and has been attributed to loss of endosymbiotic algae (zooxanthellae), loss of algal pigmentation or a combination of the two (Kleppel et al. 1989, Jokiel \& Coles 1990). Factors such as elevated seawater temperature, disease, changes in salinity, sedimentation, pollution and solar radiation, or synergistic interactions between combinations of factors, have been cited as causal agents of coral bleaching (Coles \& Jokiel 1978, Brown \& Howard 1985, Brown 1987, Glynn 1993).

While the ecological implications of bleaching have been widely discussed (see Brown 1987. Glynn 1993 for reviews) little is known of the cellular processes that lead to zooxanthella and/or pigment loss from coral tissues during bleaching. Contrasting descriptions of bleaching (mechanisms of zooxanthella loss, relative contribution of zooxanthella versus pigment

•E-mail: m.d.a.le-tissier@ncl.ac.uk loss, and the nature of pigment changes) may reflect differences between species, the nature of the stressor and/or the amount of time lapsed between the onset of bleaching and collection of samples. Laboratory-based studies are able to document changes immediately at the onset of bleaching and have described a single predominant mechanism of bleaching but in circumstances bearing little resemblance to field conditions (Brown et al. 1995). A recent histological study by Brown et al. (1995) on 6 species of naturally bleached corals, carried out $5 \mathrm{wk}$ after bleaching was first observed, revealed a number of distinct cellular processes which would result in reduced zooxanthellae densities. Studies documenting changes in zooxanthellae densities and pigment content during natural bleaching events have been carried out when bleaching was probably at an advanced stage (e.g. 6 mo; Szmant \& Gassman 1990). There are no field studies describing bleaching processes immediately at the onset of a natural bleaching event. Brown et al. (1994) have described a particular type of bleaching, induced primarily by elevated solar irradiance, whereby dis- 
crete areas of bleached tissue formed on west faces of intertidal corals on reef flats at Ko Phuket, Thailand, during periods of low spring tides correlated with high sun altitude and irradiance. These bleached areas were oriented to the sun's altitude and azimuth at the time of formation. Although bleached, the coral tissues remain viable and may subsequently recover given favourable conditions; all other tissues remain 'normally' pigmented.

For the solar bleaching response described above, analysis of tidal curves, sun altitude and azimuth allowed the position of bleaching on the coral colony and the timing of the response to be predicted in advance. This provided a unique opportunity to study natural bleaching responses in corals immediately at the onset of bleaching. This paper presents quantitative and histological evidence of cell and pigment changes in the tissues of Goniastrea aspera as a result of solar induced bleaching.

\section{MATERIALS AND METHODS}

Collection of specimens. Intertidal colonies of Goniastrea aspera (Verrill) at Phuket, Thailand (Brown et al. 1994: Site A) were subaerially exposed during a period of low spring tides from 26 to 31 March 1994. As a result of this exposure, areas of bleached tissue formed on the west-facing sides of many colonies. At the beginning of the first low tide on 26 March all colonies were naturally pigmented. On 28 March discrete areas of pale tissue had developed, and by 30 March these areas appeared white. At the beginning of the subsequent spring tides (10 April), when the colonies were next exposed, the areas of white bleached tissue had substantially regained their natural brown colouration.

All sampling involved the removal of $25 \mathrm{~mm}$ diameter circular cores of tissue and skeleton to a depth of about $15 \mathrm{~mm}$ using a battery-operated drill fitted with a hole saw bit. Cores were removed from colonies within the first 30 min of subaerial exposure. Sampling took place on 4 dates: 26, 28, 30 March and 10 April. Cores collected on 10 April were sampled from positions on colonies which had been bleached white on 30 March as identified from photographs. Colonies were randomly selected; 10 colonies were sampled on 26 March, followed by 5 new colonies on each of the other 3 dates. On $26 \mathrm{March} 3$ cores were removed from the west face of each colony, and on 28 March 3 cores were removed from west-facing pale bleached areas. On 30 March 3 cores were removed from both westfacing white bleached areas and west-facing unbleached areas adjacent to the bleached areas of each colony.
For each set of 3 cores, 1 core was used for chlorophyll analysis, 1 for measurement of zooxanthellae density, and 1 for histology. Chlorophyll cores were immediately placed on ice in a darkened container, returned to the laboratory within $1 \mathrm{~h}$ and stored in a freezer $\left(-10^{\circ} \mathrm{C}\right)$ prior to chlorophyll extraction. Zooxanthellae density cores were fixed in $10 \%$ formalin in seawater. Cores for histology were immediately anaesthetised in a $1: 1$ solution of $0.36 \mathrm{M}$ magnesium chloride and seawater for $30 \mathrm{~min}$ prior to fixation. Core surface areas were computed from diameters measured with vernier callipers.

Preparation of samples for histology. Anaesthetised cores were fixed in 3\% glutaraldehyde, $0.5 \%$ tannic acid and $7.5 \%$ sucrose in $0.1 \mathrm{M}$ sodium cacodylate for $1 \mathrm{~h}$ at ambient temperature (approx. $30^{\circ} \mathrm{C}$ ), and then $14 \mathrm{~h}$ at $4^{\circ} \mathrm{C}$. Cores were post-fixed in $1 \%$ osmium tetroxide in $0.1 \mathrm{M}$ sodium cacodylate for $2 \mathrm{~h}$. Skeleton below the tissue layer was cut away and discarded and the remaining tissue layer demineralised in a solution of $10 \%$ ascorbic acid in $0.3 \mathrm{M} \mathrm{NaCl}$ changed every $12 \mathrm{~h}$ until no skeleton remained ( $\sim 3$ to $4 \mathrm{~d}$ ). Tissues were dehydrated in a graded series of acetone, embedded in Emix resin (Bio-Rad Microscience Division) and sectioned on a Reichert Ultracut E ultramicrotome using a diamond knife. Thin sections (70 to $90 \mathrm{~nm}$ ) cut through the apex of corallite walls were collected on filmed copper slot grids, stained in lead citrate and uranyl acetate and viewed on a Phillips 100CM electron microscope. Multiple longitudinal sections of whole polyps were cut to determine the distribution of zooxanthellae in the coral tissues. Sections $10.5 \mu \mathrm{m}$ thick) were collected at intervals through each polyp, mounted on glass slides, stained with toluidine blue and viewed on a Leitz or thoplan light microscope. The density of zooxanthellae from 5 tissue areas were examined: (1) tissues overlying the apex of corallite walls, (2) tissues from a mid-corallite wall position, (3) tissues of the oral disc, (4) tissues below the oral disc, and (5) mesenterial filaments.

Preparation of samples for zooxanthellae counts. Cores fixed in $10 \%$ formalin ( $24 \mathrm{~h}$ ) were decalcified in $5 \%$ formic acid $/ 5 \%$ formalin ( $48 \mathrm{~h}$ ), and homogenised in $2 \%$ formalin using a tissue tearer (Ultra Turrax T25 at $1.3500 \mathrm{rpm}$ ). Homogenisation was considered complete when no clumps of tissue remained but zooxanthellae still appeared intact. Zooxanthellae from 3 subsamples from each core were counted microscopically on Neubauer haemocytometer slides and counts normalised to coral surface area

Preparation of samples for chlorophyll analysis. Excess skeleton below the tissue layer was cut away and discarded. Cores were then ground using a pestle and mortar in $10 \mathrm{ml} \mathrm{90 \%} \mathrm{acetone} \mathrm{following} \mathrm{the} \mathrm{method}$ of Jeffrey \& Haxo (1968). Chlorophyll absorbances 
were read at $750,665,647$ and $630 \mathrm{~nm}$ in a Whatman DC500 spectrophotometer (bandwidth $8 \mathrm{~nm}$ ) and chlorophyll $a$ and $c$ (chl $a$ and $c$ ) concentrations calculated using the equations of Jeffrey \& Humphrey (1975). The chl a component due to endolithic algae was subtracted (see Jokiel \& Coles 1974).

Statistical analysis of data. Data were tested for normality (Shapiro-Wilk), homogeneity of variance (Bartlett), and outliers (MINITAB boxplot). None of the data showed significant departures from normality. All data for chl $c$ and zooxanthellae density were homoscedastic. Data for chl a were heteroscedastic.

Homoscedastic data sets were compared using parametric ANOVA and Newman-Keuls multiple comparisons. Heteroscedastic data were compared using the Kruskal-Wallis non-parametric test, but subsequent multiple comparisons could not be made because the number of observations in each data set was too low ( $n=5$ or 10$)$

\section{RESULTS}

\section{Zooxanthellae density and chlorophyll concentration}

There was a significant difference between zooxanthellae densities of visibly unbleached, pale and white bleached tissues ( 1 -way ANOVA, $p<0.001$ ). NewmanKeuls multiple comparison tests indicated that zooxanthellae densities of pale (28 March) and white (30 March) bleached areas differed significantly both from each other and from unbleached tissues (Fig. 1). However, there was no significant difference between apparently unbleached tissues collected on 26 March and 10 April

There was no significant difference in chl a per $\mathrm{cm}^{2}$ between unbleached, pale and white bleached tissues (Kruskal-Wallis test, $\mathrm{p}<0.05$ ) (Fig. 2a). Chl a per zooxanthella varied significantly between unbleached tissues, pale, and white bleached areas (Kruskal-Wallis test, $\mathrm{p}<0.05$ ) (Fig. 2b), and increased in bleached tissues compared to normally pigmented tissues. Associated with increased chl a per zooxanthella in bleached tissues were increases in the range of (pale bleached tissues, 0.54 to $2.81 \mathrm{pg}$ per zooxanthella; white bleached tissues, 0.86 to $3.83 \mathrm{pg}$ per zooxanthella) compared to normally pigmented tissue (greatest range 0.62 to $1.65 \mathrm{pg}$ on $10 \mathrm{April}$ ).

The 1-way ANOVA showed a significant difference in both $\mathrm{chl} c$ per $\mathrm{cm}^{2}$ and chl $c$ content per zooxanthella between unbleached, pale and white bleached tissues $(p<0.008$; Fig. 2c, d). However, a Newman-Keuls multiple comparison test indicated significant differences in both $\mathrm{chl} c$ per $\mathrm{cm}^{2}$ and $\mathrm{chl} c$ content per zooxanthella only between normally pigmented tissue and bleached tissues (pale or white) (Fig. 2c, d); it showed no significant differences for these parameters between pale and white bleached tissues.

\section{Distribution and apparent density of zooxanthellae}

Results from multiple sectioning through whole polyps from bleached and normally pigmented tissues showed an even distribution of zooxanthellae overlying the apex of corallite walls (Fig. 3) and a very low density of zooxanthellae in the mesenterial filaments and below the oral disc. Sections through the midcorallite wall and oral disc showed distinct areas of relatively thick and thin endoderm associated with the architecture of the skeletal septa and ramifications of the gastrovascular canal system. The micrographs presented here (Figs. $4 \& 5$ ) of the mid-corallite wall and oral disc are from the areas of relatively thick endoderm.

Comparisons between the endoderm of normally pigmented tissues collected on 26 and on 30 March showed no apparent differences in zooxanthellae densities. In pale and white bleached tissues there were relatively few zooxanthellae in the endoderm overlying both the corallite wall apex and mid-corallite wall, compared with normally pigmented tissues. In the region of the oral disc, the endoderm of bleached white tissues had relatively few zooxanthellae compared to that of normally pigmented tissues. However, there was no apparent difference in zooxanthellae density of endoderm of the oral disc between tissues

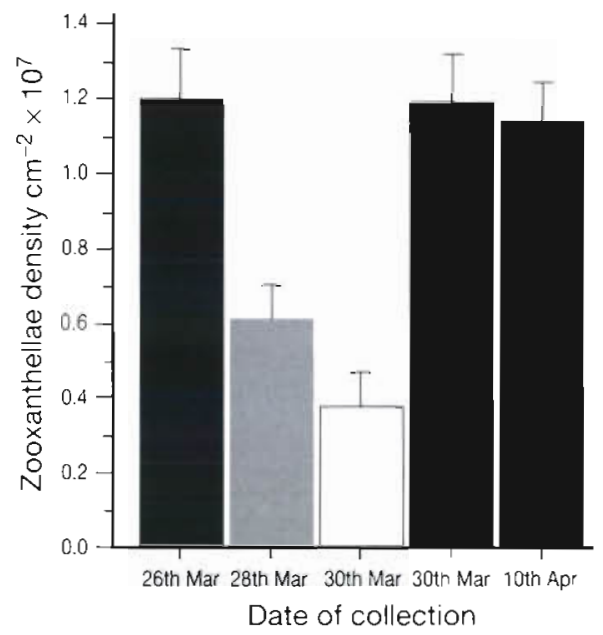

Fig. 1. Zooxanthella density in Goniastrea aspera colonies collected before (26 March), during (28 and $30 \mathrm{March}$ ) and after (10 April) the bleaching event. ( Normal brown coloured tissue, ( $\square$ ) pale bleached tissue (28 March), ( $\square$ ) white bleached tissue (30 March). Error bars are 1 standard deviation; $\mathrm{n}=10$ (26 March) and 5 (all other cases) 

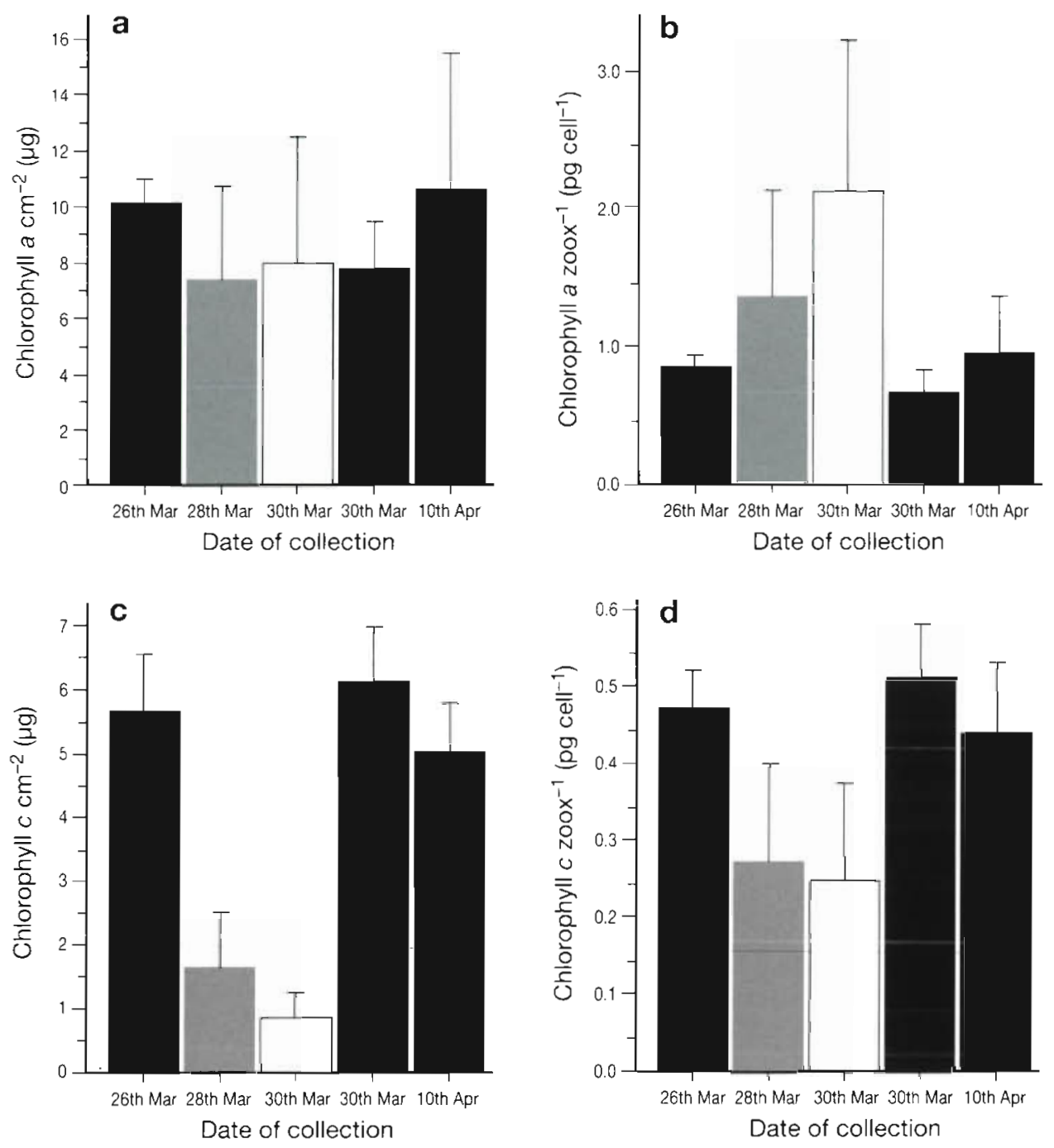
Fig. 2. (a) Chl a content per $\mathrm{cm}^{2}$, (b) chl a content per zooxanthella cell, (c) chl c content per $\mathrm{cm}^{2}$, and (d) chl $c$ content per zooxan- thella cell, from Coniastrea aspera colonies collected before (26 March), during (28 and 30 March) and after (10 April) the bleach- ing event. (a) Normal brown coloured tissue, ( $)$ pale bleached tissue (28 March), and ( $\square$ ) white bleached tissue (30 March). Error bars are 1 standard deviation; $\mathrm{n}=$ 10 (26 March) and 5 (all other cases)

from pale lesions and normally pigmented areas. Similarly, no differences in the density of zooxanthellae could be seen in tissues from below the oral disc compared to the mesenterial filaments in any samples.

\section{Ultrastructure of zooxanthellae and animal host tissues}

Examination of endoderm overlying the corallite wall apex in tissues collected on 26 March and in normally pigmented west-facing tissues on 30 March (Fig. 6a \& b respectively) showed that the majority of zooxanthellae were tightly bound within host cell vacuoles such that the symbiont/host boundaries were unclear. Small numbers of zooxanthellae were in a degraded state in these tissues (arrows on Fig. 6a, b), probably reflecting the dynamic nature of the symbi- otic relationship and natural turnover of the resident algal population. Variations in the appearance of zooxanthellae in unbleached tissue were restricted to the presence/absence of vacuole spaces between the host vacuole membrane and zooxanthella cell wall; the size of the accumulation body; and the numbers of starch granules.

In pale bleached tissues sampled on 28 March (Fig. 6c) there were obvious differences in the appearance of zooxanthellae and the endodermal cells which they occupied, when compared with non-bleached areas. The majority of zooxanthellae and their host celis exhibited various stages of cellular degradation, with an apparent gradient of degradation from proximal to distal margins of the endoderm (Figs. 6c \& 7). A wide vacuole space around the zooxanthellae and a loss of circularity were evident in most algae, with spaces separating the algal cell wall from the algal plasma membrane. At the proximal margin of the 

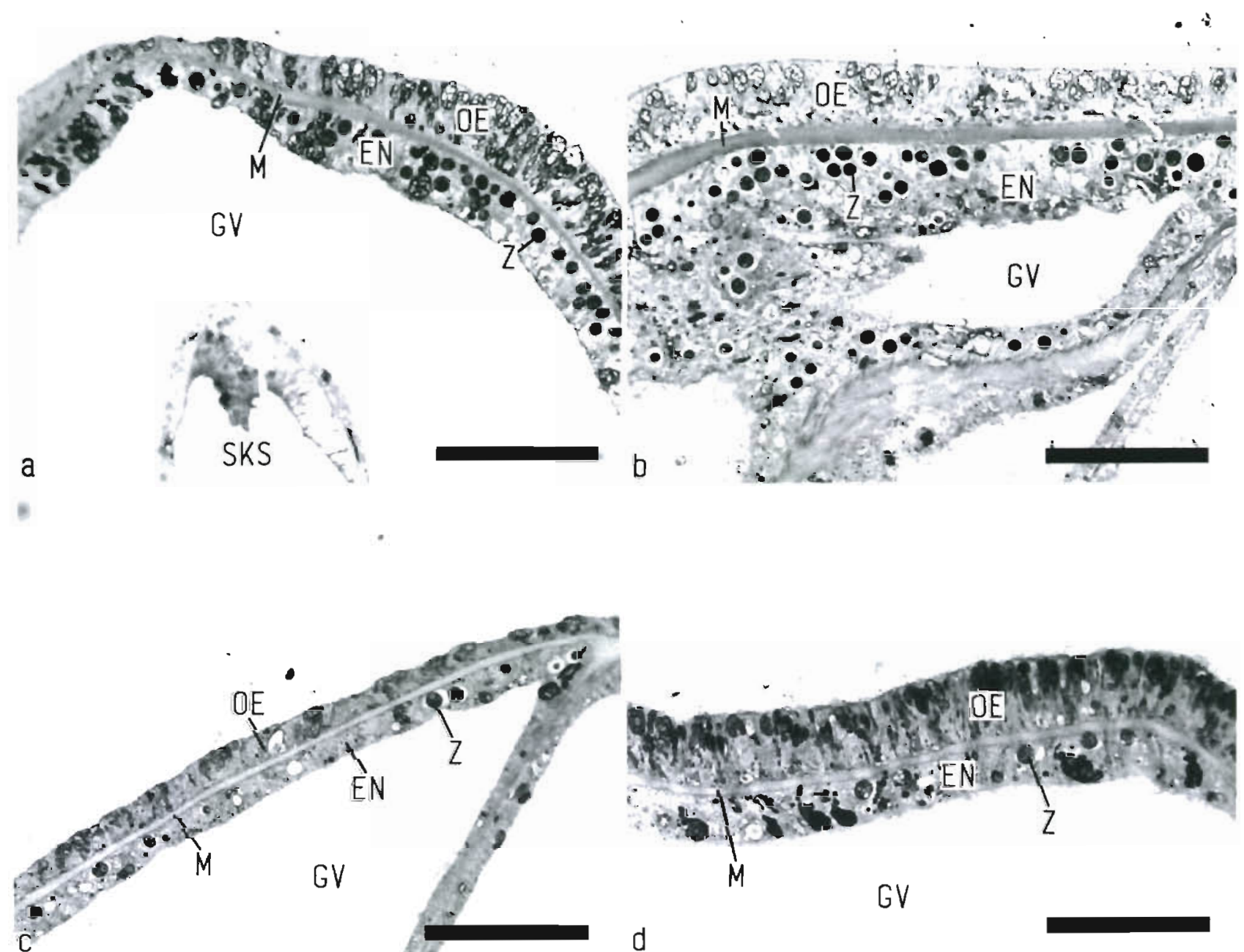

Fig. 3. Light micrographs showing the distribution of zooxanthellae within tissue overlying the apex of corallite walls on the west faces of Goniastrea aspera, from (a) normal brown coloured tissue on 26 March, (b) normal brown coloured tissue adjacent to bleached area on 30 March, (c) pale bleached area on $28 \mathrm{March}$ and (d) white bleached area on $30 \mathrm{March}$. Scale bars = $100 \mu \mathrm{m}$. $\mathrm{EN}=$ endoderm; $\mathrm{GV}=$ gastrovascular space; $\mathrm{M}=$ mesogloea; $\mathrm{OE}=$ outer ectoderm; $\mathrm{SKS}=$ skeletal space; $\mathrm{Z}=$ zooxanthella

endoderm, some cell profiles showed completely degraded algal cells and host cytoplasm (arrowhead in Fig. 6c). Those endodermal cells not harbouring an endosymbiont, including those adjacent to degraded cells, showed no signs of deterioration.

In white bleached tissues sampled on 30 March (Fig. 6d) the endoderm harboured few zooxanthellae. Vacuole spaces were again evident and the majority of zooxanthellae were in a state of cellular degradation.

\section{DISCUSSION}

The effects of temperature-induced bleaching in corals have been widely studied (see Glynn 1993 for review), however, this is the first work to document zooxanthellae density, pigment content and histological changes immediately at the onset of a solar bleach- ing event. Solar damage in intertidal reef corals appears to be highly localised, both in terms of area of tissue affected (Brown et al. 1994) and also with respect to individual cells influenced by the stress(es) involved. Damage, measured here as changes in zooxanthellae density, alterations in pigment concentration and cellular degradation, was restricted to the bleached tissues and did not affect surrounding normally coloured tissues. Within areas of bleached tissue, histological observations suggested that zooxanthellae in apically directed tissues were more affected than those located deeper in the polyps at the beginning of the bleaching response (pale tissues), with all tissue areas equally affected in fully bleached (white) tissues.

The bleaching response involved a reduction in zooxanthellae numbers, unchanged levels of chl a on an areal basis and an apparent increase in chl a content per zooxanthella, as well as a reduction in chl $c$ on 


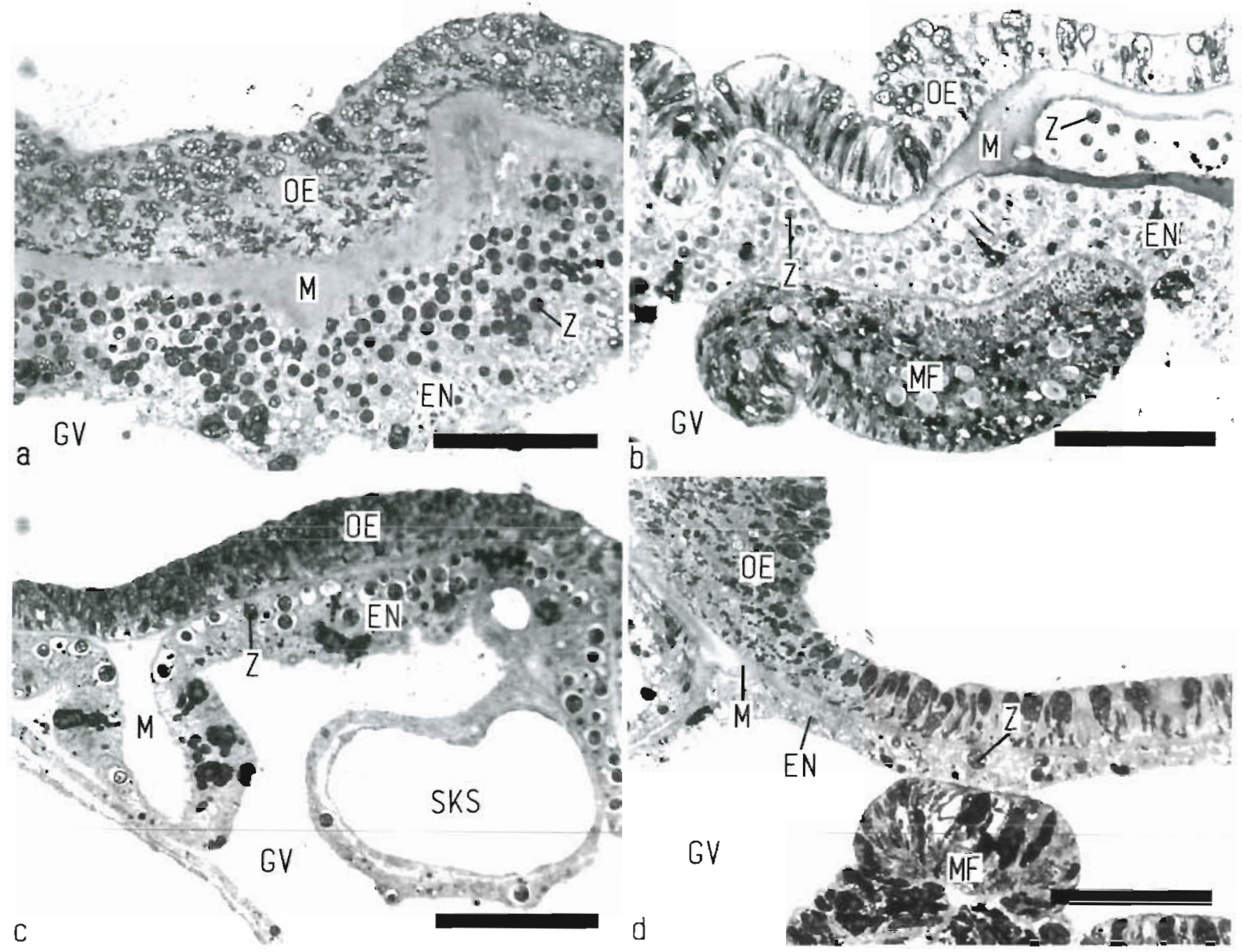

Fig. 4. Light micrographs showing the distribution of zooxanthellae within tissue overlying the mid-corallite wall on the west faces of Gonlastrea aspera, from (a) normal brown coloured tissue on 26 March, (b) normal brown coloured tissue adjacent to bleached area on $30 \mathrm{March}$, (c) pale bleached area on 28 March and (d) white bleached area on $30 \mathrm{March}$. Scale bars = $100 \mu \mathrm{m}$. $\mathrm{EN}=$ endoderm; $\mathrm{GV}=$ gastrovascular space $\mathrm{M}=$ mesogloea $; \mathrm{MF}=$ mesenterial filament $\mathrm{OE}=$ outer ectoderm; $\mathrm{SKS}=\mathrm{skeletal}$ space; $\mathrm{Z}=$ zooxanthella

an areal and per zooxanthella basis, the effects being progressive as bleaching became more advanced. Reductions in zooxanthellae numbers in naturally bleached corals have been recorded in several instances (Kleppel et al. 1989, Hayes \& Bush 1990. Szmant \& Gassman 1990, Carricart-Ganivet 1993, Brown et al. 1995), though experimental studies on the effects of increased. irradiance alone on zoanthids revealed no significant changes in zooxanthellae abundance (Lesser et al. 1990). Zooxanthellae densities of bleached tissues calculated from haemocytometer counts may not accurately estimate the viable zooxanthellae population because it is not possible to distinguish between 'normal' and degraded zooxanthella cells.

Reductions in chl $c$ concentrations have been reported both in natural bleaching events (Kleppel et al.
1989) and in experimental studies using increased irradiance (Lesser et al. 1990). Unchanged chl a levels on an areal basis and elevated content per zooxanthella found in this study and work by Carricart-Ganivet (1993) conflict with earlier observations of reduced chl a per $\mathrm{cm}^{2}$ and unchanged chl a levels per zooxanthella (Hoegh-Guldberg \& Smith 1989, Szmant \& Gassman 1990) and reduced chlorophyll concentrations on both an areal and per zooxanthella basis (Reese et al. 1988, Lesser et al. 1990, Satapoomin 1993) in bleached tissues. A possible explanation for an increase in chl a per zooxanthella is that the absorption peak (664 nm) used to compute chl a concentration is affected by breakdown products of chl a and other pigments, a factor which can only be determined by more detailed pigment analysis. Such a response is likely to be observed only when samples are collected early in the 


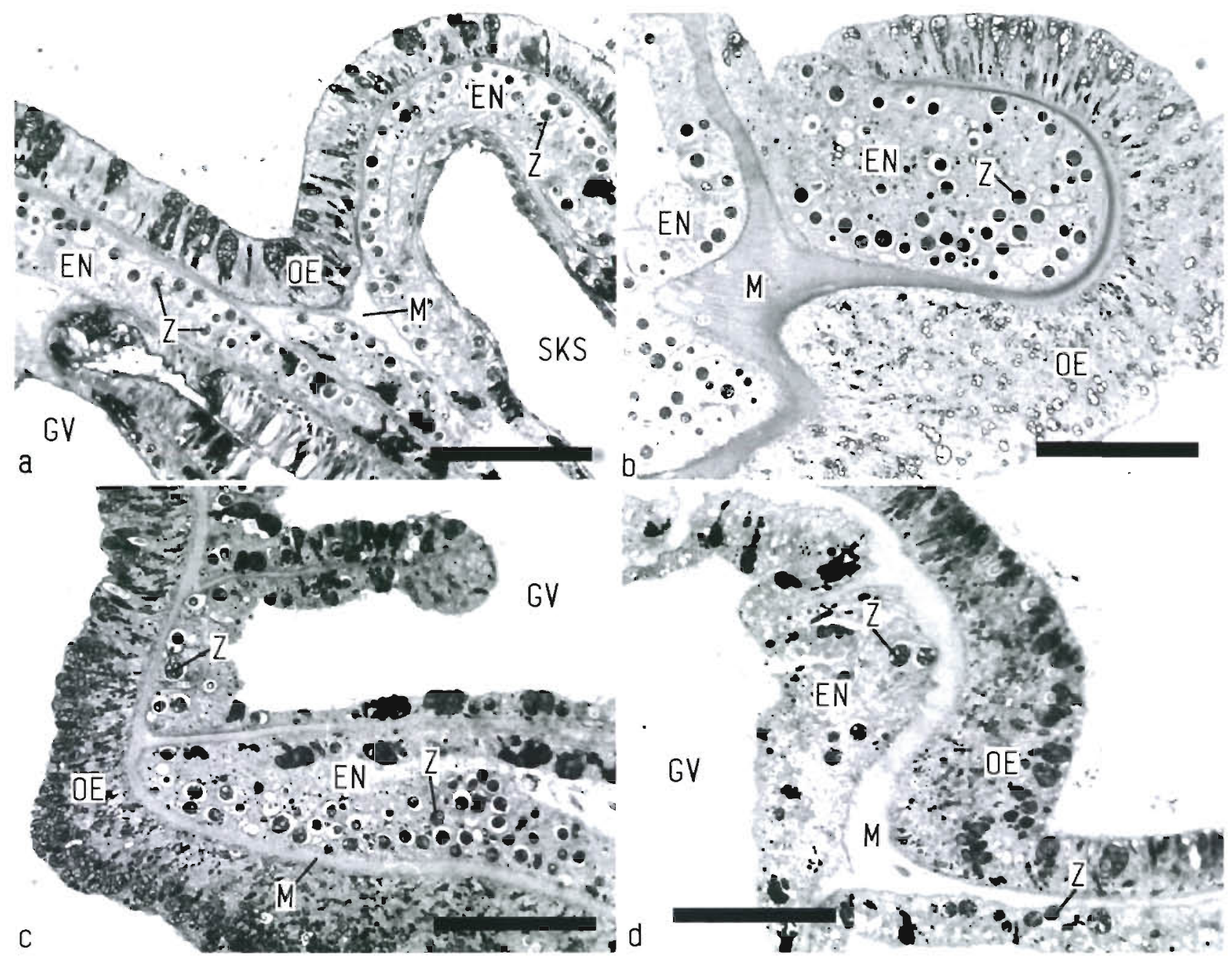

Fig. 5. Light micrographs showing the distribution of zooxanthellae within oral disc tissue on the west faces of Goniastrea aspera, from (a) normal brown coloured tissue on $26 \mathrm{March}$, (b) normal brown coloured tissue adjacent to bleached area on $30 \mathrm{March}$, (c) pale bleached area on $28 \mathrm{March}$ and (d) white bleached area on $30 \mathrm{March}$. Scale bars $=100 \mu \mathrm{m}$. EN = endoderm; GV = gastrovascular space; $\mathrm{M}=$ mesogloea $; \mathrm{OE}=$ outer ectoderm; $\mathrm{SKS}=$ skeletal space; $\mathrm{Z}=$ zooxanthella

bleaching process. High concentrations of chl a breakdown products have been observed in symbiotic algae of aquarium-maintained anemones (B. E. Brown \& I. Ambrasari pers. obs.) and foraminifera following their exposure to stressful conditions (Knight \& Mantoura 1985). The increase in the range of chl a per zooxanthella recorded in bleaching tissues would also support such a hypothesis. The possible inclusion of breakdown products affecting the chl a computation may, in part, explain why bleached tissues appear to contain significant levels of pigment $1-15 \mu \mathrm{g} \mathrm{cm}^{-2}$ of chl a and $c$ in unbleached tissues vs $\sim 9 \mu \mathrm{g} \mathrm{cm}^{-2}$ in bleached tissues on $30 \mathrm{March}$ ). Tissue retraction and a greater loss of zooxanthellae from apical tissues compared to deeper regions may also effectively hide zooxanthellae, remaining in bleached tissues and the pigment they contain (Brown et al. 1995).
Visible cellular degradation as a result of solar bleaching was confined to those endodermal cells harbouring zooxanthellae. Sequestration of zooxanthellae within a specific cell type may provide a mechanism by which the digestive processes of the endoderm are kept separate from the husbandry of the zooxanthellae population (see Trench 1979 for review). Both zooxanthellae and their host cells from bleached tissues showed a spectrum of morphologies from normal to completely degraded, suggesting that, once affected, both progressively degrade in situ prior to their loss from host tissues. A progressive gradient of increasing degradation in host and algal cells was noted from the endoderm base to the free margin of the endoderm, similar to that described by Taylor (1968) and Trench (1974) in the mesenteries of anemones and zoanthids respectively. 

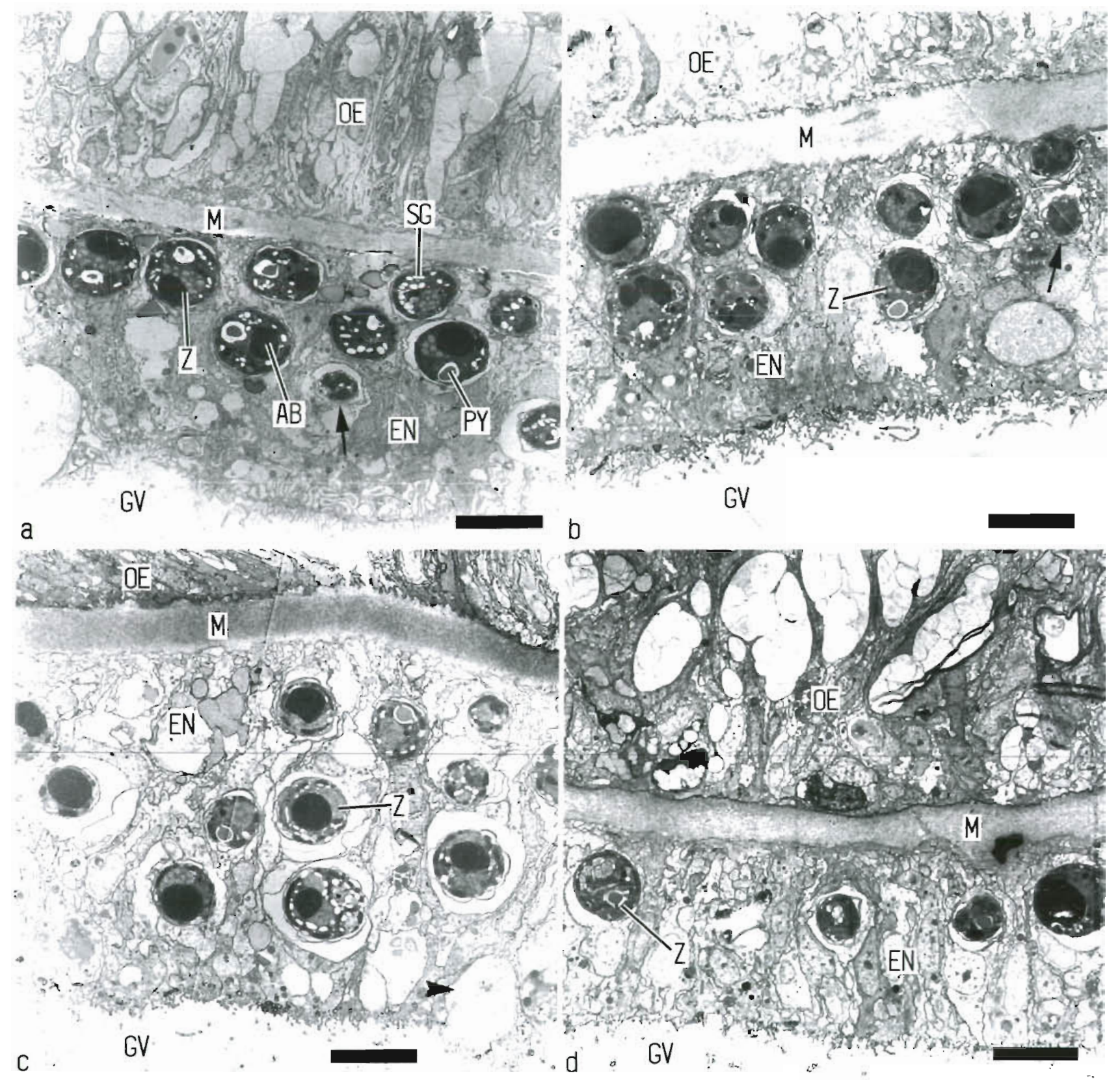

Fig 6 Electron micrographs showing zooxanthellae withın tissues overlyıng the apex of corallite walls of Goniastrea aspera, from (a) normal brown coloured tissue on $26 \mathrm{March}$, (b) normal brown coloured tissue adjacent to bleached areas on $30 \mathrm{March}$, (c) pale bleached areas on 28 March showing zooxanthella and host cells at varying stages of degradation and (d) white bleached areas on 30 March Scale bars = $10 \mu \mathrm{m} A B=$ accumulation body; $E N=$ endoderm: $G V=$ gastrovascular space; $M=$ mesogloea; $\mathrm{OE}=$ outer ectoderm, $\mathrm{PY}=$ pyrenord body; $\mathrm{SG}=$ starch granule, $\mathrm{Z}=$ zooxanthella

In situ degradation of zooxanthellae as found in the present study is simular to that described for other corals subject to natural bleaching where increased seawater temperatures were thought to be the major environmental stressor (Glynn et al 1985, Jaap 1985, Glynn \& D'Croz 1990, Brown et al. 1995) though increased irradiance could not be ruled out as a synergistic factor in any of these examples. In a controlled laboratory expenment where temperature was the only variable, Glynn \& D'Croz (1990) also demonstrated degradation of zooxanthellae in situ. Unlike some cellular mechanisms that lead to a reduction in zooxanthella numbers in coral tissues which appear to be specific to partıcular types of stress, in situ algal degradation is a cellular mechanism that appears to be common to bleaching induced by both elevated solar 
Fig. 7. Electron micrograph showing detail of degraded zooxanthellae cell and host cell in pale bleached tissue on 28 March. Scale bars $=2 \mu \mathrm{m}$. $\mathrm{AB}=$ accumulation body; $A N=$ animal nucleus; $A W=$ host cell wall $; \mathrm{CP}=$ chloroplast $\mathrm{EN}=$ endoderm; LP = lipid; PM = zooxanthella plasma membrane $; S G=$ starch granule; $V S$ = vacuole space; $Z=$ zooxanthella; $Z N=$ zooxanthella nucleus; $Z W=$ zooxanthella cell wall

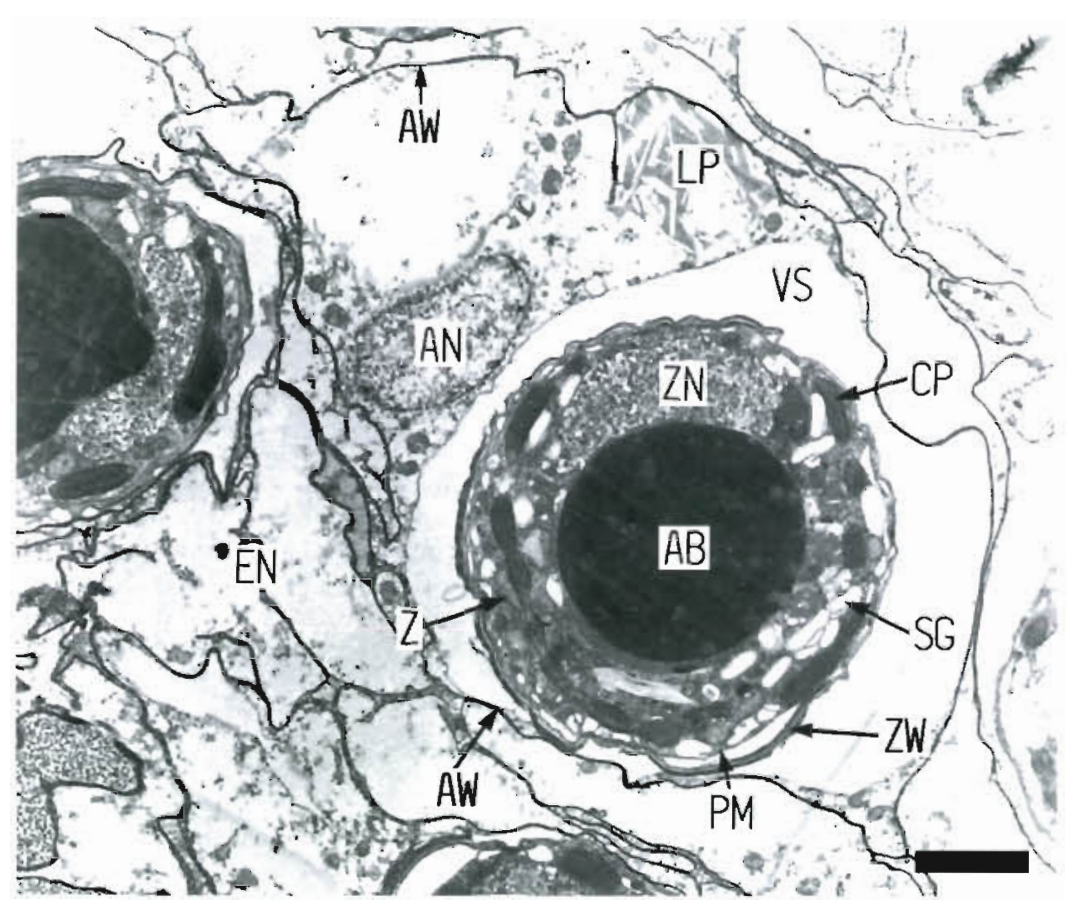

irradiance and seawater temperature (see Brown et al. 1995).

The bleached areas of tissue formed during the low spring tides of 26 to 30 March 1994 had recovered their zooxanthellae densities and pigmentation to prebleaching levels by the following low spring tides, suggesting that corals may recover very rapidly from localised solar induced bleaching, in this case within days. Previous studies of more widespread bleaching induced by sea surface temperature (Hayes \& Bush 1990, Satapoomin 1993) have demonstrated recovery of normal pigmentation in bleached corals within 6 mo. Clearly many corals have the ability to survive bleaching events, and it may be that the colonial nature of the coral and the often highly localised nature of the bleaching response, together with the ability to restrict damage at the cellular level, act to minimise damage to the coral colony.

This study has highlighted several novel findings regarding the bleaching response in corals. Firstly, during this sub-lethal bleaching event, in which solar irradiance played an important part, zooxanthellae and their host cells were targets of damage while other host tissues remained unchanged. Secondly, loss of zooxanthellae during bleaching resulted from disintegration of algae in situ rather than release of viable zooxanthellae together with host cells as reported by Gates et al. (1992). Finally, although significant reductions in accessory pigments (chl c) occurred during bleaching, variations in chl a gave equivocal results, suggesting a need to review the interpretation of chl a measurements in light of possible analytical interference from filamentous algae (Kleppel et al. 1989) and breakdown products resulting from algal degradation.

Acknowledgements. We thank the Director and staff of the Phuket Marine Biological Centre for their continued support, particularly Dr Hansa Chansang, Mr Niphon Phongsuwan and Mr Ukkrit Satapoomin. We are also grateful to the Natural Resources and Environment Department of the Overseas Development Administration (London) for funding of this project.

\section{LITERATURE CITED}

Brown BE (1987) Worldwide death of corals - natural cyclical events or man-made pollution? Mar Pollut Bull 18:9-13

Brown BE, Dunne RP, Scoffin TP, Le Tissier MDA. (1994) Solar damage in intertidal corals. Mar Ecol Prog Ser 105:219-230

Brown BE, Howard LS (1985) Assessing the effects of stress on reef corals. Adv Mar Biol 22:1-63

Brown BE, Le Tissier MDA, Bythell JC (1995) Mechanisms of bleaching deduced from histological studies of reef corals sampled during a natural bleaching event. Mar Biol 122: $655-663$

Carricart-Ganıvet JP (1993) Partıal whitening in Porites porites (Cnudaria: Scleractinla) at the Isla Verde Reef Veracruz, Mexico. Rev Biol Trop 41:495-498

Coles SL, Jokiel PL. (1978) Synergistic effects of temperature, salinity and light on the hermatypic coral Montipora verrucosa (Lamarck). Mar Biol 49:187-195

Gates RD, Baghdasarian G, Muscatine L (1992) Temperature stress causes host cell detachment in symbiotıc cnidarians: implications for coral bleaching. Biol Bull 182:324-332

Glynn PW (1993) Coral-reef bleaching-ecological perspectives. Coral Reefs 12:1-17

Glynn PW, D'Croz I (1990) Experimental evidence for high temperature stress as the cause of El Niño-coincident coral mortality. Coral Reefs 8:181-192 
Glynn PW, Peters EC, Muscatine L (1985) Coral tissue microstructure and necrosis: relation to catastrophic coral mortality in Panama. Dis Aquat Org 1:29-38

Hayes RL. Bush PG (1990) Microscopic observations of recovery in the reef-building scleractinian coral, Montastrea annularis, after bleaching on a Cayman reef. Coral Reefs 8:203-210

Hoegh-Guldberg O. Smith GJ (1989) The effect of sudden changes in temperature, light and salinity on the population density and export of zooxanthellae from the reef corals Stylophora pistillata Esper and Seriatopora hystrix Dana. J Exp Mar Biol Ecol 129:279-304

Jaap WC (1985) An epıdemic zooxanthellae expulsion during 1983 in the lower Florida Keys coral reefs: hyperthermic etiology. Proc 5th Int Coral Reef Congr 6:143-148

Jeffrey SW, Haxo FT (1968) Photosynthetic pigments of symbiotic dinoflagellates (zooxanthellae) from corals and clams. Biol Bull 135:149-165

Jeffrey SW, Humphrey GP (1975) New spectrophotometric equations for determining chlorophylls $\mathrm{a}, \mathrm{b}$, and $\mathrm{c} 1$ and $\mathrm{c} 2$ in higher plants, algae and natural phytoplankton. Biochem Physiol Pflanzen 167:191-194

Jokiel PL, Coles SL (1974) Effects of heated effluent on hermatypic corals at Kahe Point, Oahu. Pacif Sci 28:1-18

Jokiel PL, Coles SL (1990) Response of Hawailan and other Indo-Pacific reef corals to elevated temperature. Coral Reefs 8:155-162

Kleppel GS, Dodge RE, Reese CJ (1989) Changes in pig-

This article was submitted to the editor mentation associated with the bleaching of stony corals Limnol Oceanogr 34:133î-1335

Knight R, Mantoura RFC (1985) Chlorophyll and carotenoid pigments in Foraminifera and their symbiotic algae analysis by high performance liquid chromatography. Mar Ecol Prog Ser 23:241-249

Lesser MP, Stochaj WR, Tapley DW, Shick JM (1990) Bleaching in coral reef anthozoans: effects of irradiance, ultraviolet radiation, and temperature on the activities of protective enzymes agaunst active oxygen. Coral Reefs 8:225-232

Reese CJ, Kleppel GS, Dodge RE (1988) The physiological implications of bleaching of corals off southeast Florida. Proc Assoc Is Mar Lab Carib 21:66

Satapoomin U (1993) Responses of corals and coral reefs to the 1991 coral reef bleaching event in the Andaman Sea, Thailand. MSc thesis, Chulalongkorn University, Bangkok

Szmant AM, Gassman NJ (1990) The effects of prolonged 'bleaching' on the tissue biomass and reproduction of the reef coral Montastrea annularis. Coral Reefs 8:217-224

Taylor DL (1968) In situ studies on the cytochemistry and ultrastructure of a symbiotic marine dinoflagellate. J Mar Biol Ass UK 48:349-366

Trench RK (1974) Nutritional potentials in Zoanthus sociatus (Coelenterata, Anthozoa). Helgoländer Wiss Meeresunters $26: 174-216$

Trench RK (1979) The cell biology of plant-animal symbiosis. A Rev Plant Physiol 30:485-531

Manuscript first received: November 6, 1995 Revised version accepted: January 17, 1996 